Section Editor

Mitchell S.V. Elkind, MD, MS

Vivek B. Kalra, MD

Balaji Rao, MD

Ajay Malhotra, MD

Correspondence to

Dr. Kalra:

Vivek.kalra@yale.edu
Download teaching slides: www.neurology.org

\section{Teaching NeuroImages: \\ Perfusion imaging of cerebral hyperperfusion syndrome following revascularization}

Figure $\quad$ CT perfusion performed 1 day following left carotid endarterectomy
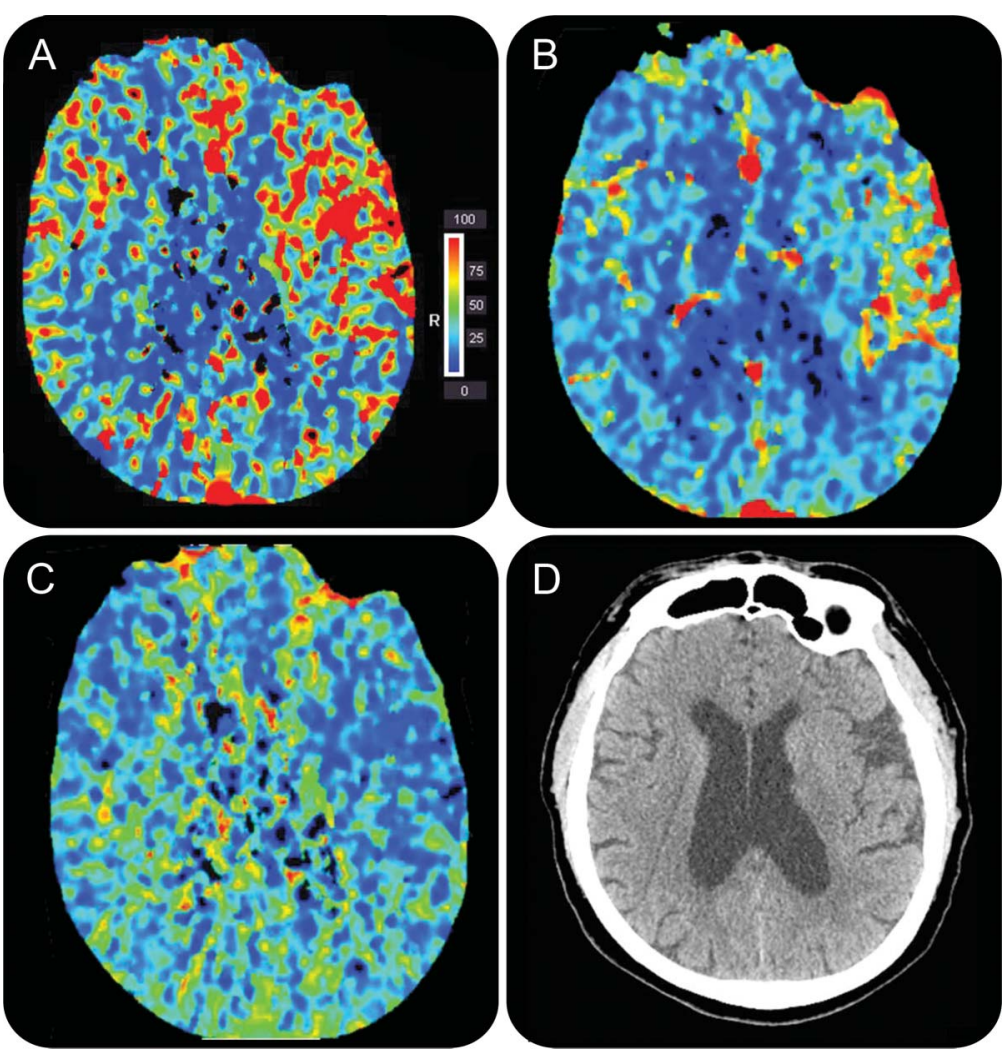

CT shows left middle cerebral artery distribution increased relative cerebral blood flow (A), increased relative cerebral blood volume $(B)$, and decreased mean transit time (C)-findings are consistent with cerebral hyperperfusion syndrome following revascularization. Noncontrast CT shows no hemorrhage or edema (D).

A 69-year-old man developed acute-onset confusion and hypertension with systolic pressures in the $160 \mathrm{~s}$ 1 day after carotid endarterectomy for right facial droop from left hemispheric lacunar infarcts. CT perfusion (figure, A-D) demonstrated findings consistent with cerebral hyperperfusion syndrome (CHS) following revascularization. CHS is caused by loss of autoregulation, hypertension, and ischemia-reperfusion injury resulting in increased regional blood flow and vascular congestion. ${ }^{1} \mathrm{CHS}$ following revascularization may present as ipsilateral headache, focal seizure, or neurologic deficit. Nonperfusion imaging may show intraparenchymal hemorrhage or edema. Labetalol and clonidine are used for aggressive blood pressure control until cerebral autoregulation is restored. $^{2}$

\section{AUTHOR CONTRIBUTIONS}

Vivek Kalra: drafting/revising the manuscript, analysis or interpretation of data, accepts responsibility for conduct of research and will give final approval. Balaji Rao: study concept or design, analysis or interpretation of data, accepts responsibility for conduct of research and will give final approval, acquisition of data. Ajay Malhotra: drafting/revising the manuscript, study concept or design, analysis or interpretation of data, accepts responsibility for conduct of research and will give final approval, acquisition of data, study supervision.

From the Department of Diagnostic Radiology, Yale-New Haven Medical Center, Yale University, New Haven, CT.

Go to Neurology.org for full disclosures. Funding information and disclosures deemed relevant by the authors, if any, are provided at the end of the article. 
STUDY FUNDING

No targeted funding reported.

\section{DISCLOSURE}

The authors report no disclosures relevant to the manuscript. Go to Neurology.org for full disclosures.
REFERENCES

1. Adhiyaman V, Alexander S. Cerebral hyperperfusion syndrome following carotid endarterectomy. QJM 2007;100: 239-244.

2. van Mook WN, Rennenberg RJ, Schurink GW, et al. Cerebral hyperperfusion syndrome. Lancet Neurol 2005;4:877-888. 


\section{Neurology}

\section{Teaching NeuroImages: Perfusion imaging of cerebral hyperperfusion syndrome following revascularization}

Vivek B. Kalra, Balaji Rao and Ajay Malhotra

Neurology 2013;81;e25-e26

DOI 10.1212/WNL.0b013e31829c5cae

This information is current as of July 22, 2013

Updated Information \&
Services
Supplementary Material
References
Subspecialty Collections
Permissions \& Licensing
Reprints

Updated Information \&

Supplementary Material

\section{References}

Reprints including high resolution figures, can be found at: http://n.neurology.org/content/81/4/e25.full

Supplementary material can be found at: http://n.neurology.org/content/supp1/2013/07/21/81.4.e25.DC1

This article cites 2 articles, 0 of which you can access for free at: http://n.neurology.org/content/81/4/e25.full\#ref-list-1

This article, along with others on similar topics, appears in the following collection(s):

\section{All Cerebrovascular disease/Stroke}

http://n.neurology.org/cgi/collection/all_cerebrovascular_disease_strok e

CT

http://n.neurology.org/cgi/collection/ct

Information about reproducing this article in parts (figures,tables) or in its entirety can be found online at:

http://www.neurology.org/about/about_the_journal\#permissions

Information about ordering reprints can be found online:

http://n.neurology.org/subscribers/advertise

Neurology ${ }^{\circledR}$ is the official journal of the American Academy of Neurology. Published continuously since 1951, it is now a weekly with 48 issues per year. Copyright () 2013 American Academy of Neurology. All rights reserved. Print ISSN: 0028-3878. Online ISSN: 1526-632X.

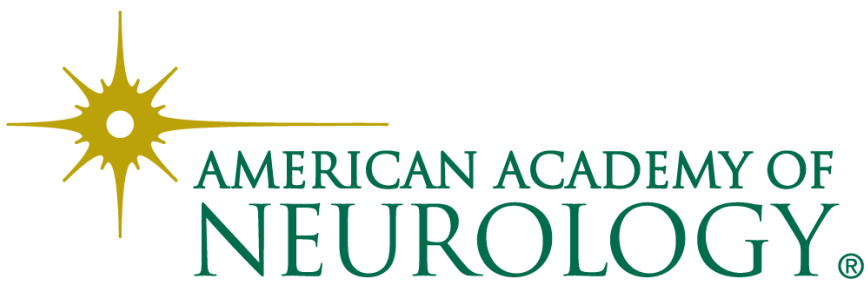

